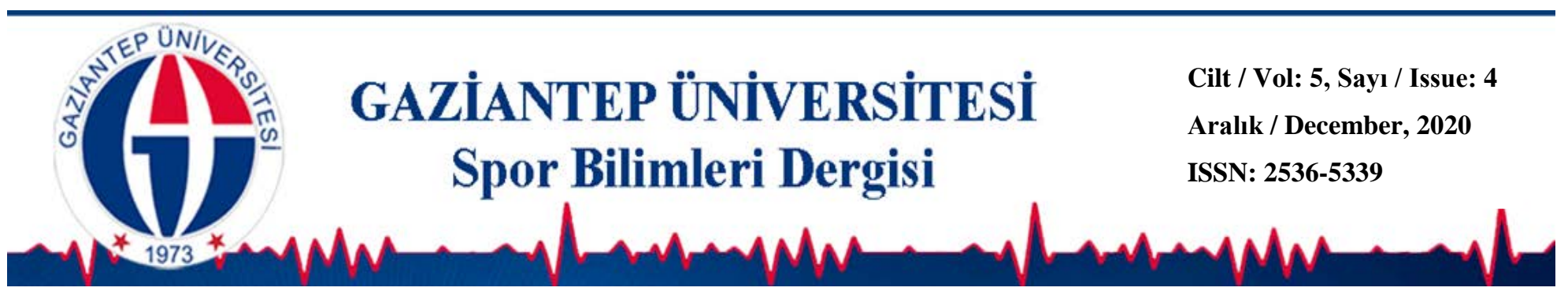

\title{
Elit Yüzme Sporcularının Egzersiz Bağımlılığı Düzeylerinin İncelenmesi
}

\author{
Batuhan BATU ${ }^{1 *}$ (D) \\ Ali Dursun AYDIN² (i \\ ${ }^{1}$ Kafkas Üniversitesi, KARS \\ ${ }^{2}$ Burdur Mehmet Akif Ersoy Üniversitesi Spor Bilimleri Fakültesi, BURDUR
}

\section{DOI: 10.31680/gaunjss.805038}

Orijinal Makale / Original Article

Geliş Tarihi / Received: 04.10 .2020
Kabul Tarihi / Accepted: 14.10.2020
Yayın Tarihi / Published: 14.12.2020

Öz

Araştırmada elit yüzme sporcularının egzersiz bağımlıı̆ı düzeylerinin incelenmesi amaçlanmıştır. Araştırmaya lisansı olan sporcular katılmıştır. Araştırmanın çalışma grubu Türkiye Yüzme Federasyonu'nda aktif durumda olan 82 kadın, 55 erkek, toplamda 137 elit sporcudan oluşmaktadır. Araştırmada "Kişisel Bilgi Formu" ve Demir, Hazar ve Cicioğlu (2018) tarafından geliştirilen "Egzersiz Bağımlılığı Ölçeği" veri toplama aracı olarak kullanılmıştır. Araştırmada sporcuların yaşı ile bireysel-sosyal intiyaçların ertelenmesi ve çatışma alt boyutu arasında negatif yönde orta düzeyde anlamlı ilişki saptanmıştır. Araştırmaya katılan sporcuların yüzme stilleri ile egzersiz bağımlılı̆ı düzeyleri arasındaki farklılık incelendiğinde sırt üstü yüzen katılımcıların serbest ve kurbağalama yüzen katılımcılara oranla egzersiz bağımlıı̆̆ puanlarının daha yüksek olduğu tespit edilmiştir. Cinsiyet, spor yaşı ve egzersiz yapma sıklığı ile egzersiz bağımlıığı alt boyutları arasında anlamlı bir farklılık görülmemiştir. Araştırmada elit yüzme sporcularının egzersiz bağımlılığı düzeylerinin bağımlı grupta yer aldığı sonucuna varılmıştır.

Anahtar Kelimeler: Spor, yüzme, egzersiz, bağımlılık, egzersiz bağımlıı̆ı

\section{Examination of Exercise Addiction Levels of Elite Swimming Athletes}

\begin{abstract}
In the study, it was aimed to examine the exercise addiction levels of elite swimming athletes. Licensed athletes participated in the study. The sample of the study consists of 137 elite athletes, 82 female and 55 male, who are active in the Turkish Swimming Federation. In the research, "Personal Information Form" and "Exercise Addiction Scale", which was developed by Demir, Hazar and Cicioğlu (2018), were used as data collection tools. In the study, a moderately negative relationship was found between the age of athletes and the sub-dimensions of postponement of individual-social needs and conflict. When examining the difference between the swimming styles and exercise addiction levels of the athletes participating in the research, it was found that the participants who were swimming the backstroke had higher exercise addiction scores than the participants swimming freestyle and breaststroke. There was no significant difference between gender, sports age and frequency of exercising and the sub-dimensions of exercise addiction. In the study, it was concluded that the exercise addiction levels of elite swimming athletes are in the dependent group.
\end{abstract}

Keywords: Sport, swimming, exercise, addiction, exercise addiction

\footnotetext{
* Sorumlu Yazar: Batuhan BATU
}

E-mail: bthn_86@hotmail.com 


\section{Giriş}

Spor; bireylerin yetenek gelişimine, bedensel ve zihinsel anlamda katkı sağlayan, herhangi bir rekabet için ya da belirli bir hedefe ulaşabilmek amacıyla birtakım kurallar dahilinde bireysel veya grup halinde sergilenen bedensel etkinlikler bütünüdür (Tanrıverdi, 2012). Diğer bir ifadeyle spor, bireyin fizyolojik ve psikolojik yönden sağlığına olumlu anlamda katkı sağlayan, sosyal davranışlarına yön veren, zihinsel ve motor beceri anlamında gelişime yardımcı olan biyolojik ve sosyal bir olgudur (Yılmaz, Şentürk, \& Ramazanoğlu, 2014). Spor kendi içinde dallara ayrılmaktadır. Bu spor dallarından biri de yüzme sporudur.

Yüzme, suda batmamak için bacakların ve kolların birlikte veya bağımsız şekilde kullanılmasıyla su yüzeyinde yatay hareketin uygulanmasıdır. Bu bağlamda yüzme, suyun nefes alıp vermeyi zorlaştıran baskısına maruz kalma, suyun içinde hareket etmeyi kısıtlayan sürtünmeye karşı koyabilme veya oluşan sürtünmeyi en aza indirmeye çalışma, su içinde enerji harcama gibi birçok özelliği ile diğer spor dallarından ayrılır (Odabaş,2003). Yüzme su içerisinde mesafe kat edebilmek için yapılan koordineli hareketlerin tamamıdır. Yüzme sporu ise sporcunun serbest, sırt, kurbağalama ve kelebek teknikleriyle belirli bir mesafeyi su içerisinde zamana karşı kat edebilme becerisidir (Hanula, 2001). Yüzme sporu, yerçekimi kuvvetinin en az etki ettiği bir spor dalı olduğu için kasların uyum içinde çalışmasına uygun bir ortam yaratır ve su direncine karşı kuvvet uygulandığı için herhangi yıpratıcı bir durum olmaksızın vücut direncini arttııır, kasların bakışımlı ve denge içeren bir biçimde gelişimini sağlar (Bozdoğan, 2006). Gonul ve arkadaşları (2016) yüzme sporunun fiziksel, zihinsel, kültürel gelişimi desteklediği, psikolojik açıdan iyi oluş, sosyalleşme, sağlıklı olma, boş zaman değerlendirme gibi çıktılarının, bireylerde egzersize katıım alışkanlığı sağladığını belirtmiştir.

Egzersiz, fiziksel uygunluğun, dayanıklıık, esneklik gibi birçok bileşeninin stabil kalmasını veya geliştirilmesini hedef alan düzenli, planlı ve tekrarlanması gereken fiziksel aktiviteler bütünüdür (Özer , 2013). Egzersiz, bireylerin gün içindeki problemlerini ve kaygılarını aza indirmek için de önemli bir etkendir. Buna göre egzersizin kişilere hem bedensel hem de ruhsal yönden yararlı olduğu söylenebilir (Demir ve Türkeli, 2019). Spora karşı ilginin oluşmasında ve devam ettirilmesinde büyük önem taşıyan egzersiz, bireylerin yaşantılarında kalıcı etkiler bırakmaktadır (Turkay ve ark., 2019). Oksijen dağılımını ve metabolik süreçleri düzene koymayı, kuvveti, dayanıkııı̆ı geliştirmeyi, vücuttaki yağ oranını aza indirmeyi, kas-eklem 
Batu, B. ve Aydın, A.D. (2020). Elit Yüzme Sporcularının Egzersiz Bağımlılığı Düzeylerinin İncelenmesi. Gaziantep Üniversitesi Spor Bilimleri Dergisi, 5(4), 399-412.

hareket alanlarını genişletmeyi amaçlayan egzersizin (Menteş, Menteş, \& Karacabey, 2011), faydaları bu kavramın bilinen yüzü olsa da peyderpey ağırlaşan, vücudu tüketen ve yıpratan, vazgeçilmesi neredeyse imkânsız hale gelen egzersizlerin zararlı yönleri de vardır (Berczik \& ark, 2012). Bilinçli, düzenli, disiplinli ve optimal düzeyde egzersiz yapılmadıkça başarısızlık vazgeçilmezdir. Egzersiz düzeyini optimal düzeyde tutmak en çarpıcı noktadır. Çünkü yoğun egzersiz aynı zamanda başarılı bir sporcunun başarısız olmasına neden olabilir (Çetin ve ark., 2020). Egzersizin bireyin kontrolünden çıkması, bu duruma karşı bağımlı olduğunun göstergesi olarak kabul edilebilir (FZmijewsk \& Howard, 2000).

Bağımlılık, bir kişiye veya nesneye karşı duyulan, fiziksel ya da psikolojik anlamda zarar görülmesine rağmen karşı koyulamaz bir istek olarak tanımlanmaktadır. Uzun yıllar ruhsal bağımlılık ve fiziksel bağımlılık olarak iki farklı şekilde değerlendirilmiştir. Kişinin duygusal olarak ve tatmin amaçlı madde kullanımı ruhsal bağımlılık, kullanılan maddeyi fizyolojik olarak istemesi ise fiziksel bağımlılık olarak tanımlanır (Ögel,1997 Akt: Cicioğlu ve ark., 2019). Bağımlılık belirtisi davranışlar yıllar boyunca yalnızca alkol ve uyuşturucu madde kullanımlarıyla sınırlandırılmış olsa da günümüzde egzersiz, internet kullanımı, kumar, cinsellik gibi birçok davranışı da kapsaması nedeniyle kapsamının genişlediği söylenebilmektedir (Demir ve ark.,2018).

Egzersiz bağımlısı olan bireyler, egzersiz yapmaya karşı koyamamaları, gün geçtikçe egzersiz yoğunluğunu artırma ihtiyacı hissetmeleri, egzersiz yapamama durumunda kaygılanma, planlanan egzersiz süresini aşmaları, egzersize çok fazla zaman harcamaları, sosyal çevre ile etkileşim yerine egzersiz yapmayı tercih etme semptomlarıyla tanınırlar. Egzersizin "karanlık yüzü” olarak adlandıran ve bir hastalık olarak nitelendirilen egzersiz bağımlılığının (Demir ve Türkeli, 2019), önemli bulgularından biri de sakatlık, hastalık, çalışma hayatı ve çevresiyle ilgili belirli bir çerçeve olmasına rağmen egzersize harcanan sürenin kontrol edilememesidir. Bireyin egzersiz programlarına göre şekillenip, kendi hayatını ve yaşam tarzını buna bağlı olarak uyarlamasıdır. Egzersiz bağımlılığında probleme sebep olan şey egzersizin işlev kaybına neden olacak kadar tutku ile yapılmasıdır. Egzersize karşı duyulan ruhsal ve fiziksel bağ egzersizin bırakılmama sebebidir (Polat \& Şimşek, 2015). Bu noktada egzersiz yapamayan bireyde, asabilik, gerginlik, huzursuzluk, uykusuzluk, duyarsızlık, hazda azalma, tembellik ve baş ağrıları gibi egzersiz bağımlılığının olumsuz yönleri ortaya çıkabilir (Koruç \& Arsan, 2009). Egzersiz 
Batu, B. ve Aydın, A.D. (2020). Elit Yüzme Sporcularının Egzersiz Bağımlılı̆̆ı Düzeylerinin İncelenmesi. Gaziantep Üniversitesi Spor Bilimleri Dergisi, 5(4), 399-412.

bağımlılığının sporcu performansıyla da ilişkili olduğu bilinmektedir. Aralarındaki bu ilişki belirsizdir, sporculardaki yüksek-* bağımlılık düzeyi kötü performansa mı sebep olur yoksa performans kaybı bağımlılığın seviyesini mi artıır? Dahası, yüksek seviyeli egzersiz uyumu, sporcuların psikolojik ve sosyolojik durumlarının yanı sıra fizyolojik parametrelerde ve en önemlisi rekabet performansında bir düşüşe yol açabilir (Çetin ve ark., 2020). Söz konusu kriterler nedeniyle bir bozukluk olarak kabul edilen egzersiz bağımlılığı kavramı günümüzde tanımlanan tüm bağımlılıklarla aynı doğrultuda değerlendirilmektedir (Vardar, 2012).

Amerikan Psikiyatri Birliği'ne (2001) göre DSM-IV'e göre egzersiz bağımlılı̆̆ı yedi belirtiden oluşmaktadır. Bir yıllık süreçte bu yedi belirtiden üçünün görülmesi bir bireyin egzersiz bağımlısı tanısının konması için yeterlidir. Bu belirtiler şunlardır: Tolerans, istenilen sonucu alabilmek adına yapılan egzersizde yoğunluğun artırılması veya aynı yoğunlukta yapılan egzersizden beklenen etkinin karşılanamamasıdır. Egzersiz bağımlılığının belirleyicilerinden bir diğeri egzersizin kesilmesi etkisidir. Egzersizin kesilmesi etkisi egzersiz yapmamanın sonucunda hissedilen endişe, yorgunluk duyguları kapsar. Ayrıca bireyin rahatlamak için aynı ölçüde egzersiz yapması olarak ifade edilir. Egzersiz süresinin ve miktarının planlanandan daha farklı olması bir diğer belirti olan niyet etkisidir. Söz konusu belirtilerden kontrol kaybı, yapılan egzersiz şiddetinde artış isteği, egzersizi kontrol etme ya da egzersizi bırakma isteğinin zıttı durumlar yaşamaktır. Zaman ise egzersiz yapmak için ayrılan zamanın çok olması durumudur. Egzersiz yapabilmek için çevresi ve iş hayatı ile ilgili aktivitelerini ya da boş zaman aktivitelerini azaltmak veya vazgeçmek diğer aktiviteleri azaltmak olarak adlandırılır. Devamlılık ise fizyolojik veya fiziksel bir sorun yaşanması halinde bu durumu görmezden gelip egzersize devam etmektir.

Bireylerin sosyalleşme, bedensel, zihinsel, duygusal açıdan sağlıklı bireyler olarak nitelendirilmesinde sporun ve egzersizin önemli bir rolü vardır. Fakat aşırı düzeyde ve kontrol edilemeyen egzersizler, fayda yerine bağımlılık gibi kötü sonuçlar doğurabilmektedir (Demir ve ark., 2018). Bu bağlamda yerli ve yabancı literatürde elit yüzme sporcularının egzersiz bağımlılığı düzeylerinin incelendiği bir araştırmaya rastlanmamıştır. Performans gelişimi adına düzenli egzersiz yapması gereken yüzme sporcuları için egzersiz bağımlılğı düzeylerinin incelenmesi önemlidir. Bu araştırmada elit yüzme sporcularının çeşitli değişkenlere göre egzersiz bağımlılığı düzeylerinin incelenmesi amaçlanmıştır. 
Batu, B. ve Aydın, A.D. (2020). Elit Yüzme Sporcularının Egzersiz Bağımlılığı Düzeylerinin İncelenmesi. Gaziantep Üniversitesi Spor Bilimleri Dergisi, 5(4), 399-412.

\section{Yöntem}

\section{Araştırmanın Modeli}

$\mathrm{Bu}$ araştırma nicel modellerden tarama yöntemine göre desenlenmiştir. Tarama yöntemi, belli bir değişkenin var olan durumunu olduğu şekliyle betimlemeyi amaçlamaktadır (Yıldırım ve Akın, 2017).

\section{Evren ve Örneklem}

Çalışma grubu Türkiye Yüzme Federasyonu'nda aktif olan lisanslı sporcuları kapsamaktadır. Bu bağlamda araştırmanın çalışma grubunu 82 kadın, 55 erkek olmak üzere 137 elit sporcu oluşturmaktadır. Araştırmanın çalışma grubu seçiminde ölçüt örnekleme yönteminden yararlanılmıştır. Bu bağlamda araştırmaya dahil edilen katılımcılara lisanslı sporcu olma kriteri konmuş, bu kriteri taşıyan bireyler araştırmaya dahil edilmiştir. Araştırmada amaçlı örnekleme yöntemlerinden ölçüt örnekleme kullanılmıştır (Patton, 2014).

\section{Verilerin Toplanması}

Egzersiz Bağımlılığı Ölçeği (EBÖ): Demir, Hazar ve Cicioğlu (2018) tarafından geliştirilen 17 madde ve 3 faktörden oluşan ölçek kullanılmıştır. EBÖ beşli likert tipinde bir derecelemeye sahiptir. EBÖ'nün puan aralıkları,“1-17 normal grup, 18-34 az riskli grup, 35-51 risk grubu, 52-69 bağımlı grup, 70-85 yüksek düzeyde bağımlı grup" şeklindedir. Egzersiz bağımlılığı düzeylerini ölçmek amacıyla kullanılan EBÖ'nün örneklem grubu için güvenirliği test edilmiştir. Bu doğrultuda EBÖ'nün Cronbach Alpha değeri "Aşırı Odaklanma ve Duygu Değişimi” için ,88; "BireyselSosyal İhtiyaçların Ertelenmesi ve Çatışma” için ,89; “Tolerans Gelişimi ve Tutku” için ,86'dır. Ölçekte ters (olumsuz) madde bulunmamaktadır. Cronbach Alpha katsayısı 0,40'dan düşük olması güvenilir olmadığını ve ,79-,86 aralığı ise ölçme aracının güvenilir olduğunu gösterir (Büyüköztürk, 2014).

\section{Verilerin analizi}

Değişkenlere normallik testi ve varyansların homojenliği için "KolmogorovSmirnov Testi" ile "Levene Testi” yapılmıştır. Bu testler sonucunda değişkenlerin dağıımının \pm 1 aralığında olmadığı saptanmış ve değişkenlere non-parametrik testler uygulanmıştır (Büyüköztürk, 2014). Araştırmaya katılan katılımcıların egzersiz bağımlılığı puanlarını belirlemek için spearman korelasyon analizi, Mann-Whitney U 
Batu, B. ve Aydın, A.D. (2020). Elit Yüzme Sporcularının Egzersiz Bağımlılığı Düzeylerinin İncelenmesi. Gaziantep Üniversitesi Spor Bilimleri Dergisi, 5(4), 399-412.

Testi ve Kruskal-Wallis Testinden yararlanıImıştır. Buna göre, Mann-Whitney U Testi için "Z" dağııımı istatistiği, "Kruskal-Wallis Testi için "Ki-Kare" dağılımı istatistiği dikkate alınmıştır. Uygulanan istatistiki testlerde güven düzeyi ,05 olarak esas alınmıştır.

\section{Bulgular}

Tablo 1. Yaşa Göre Yapılan Spearman Korelasyon Analizi Sonuçları

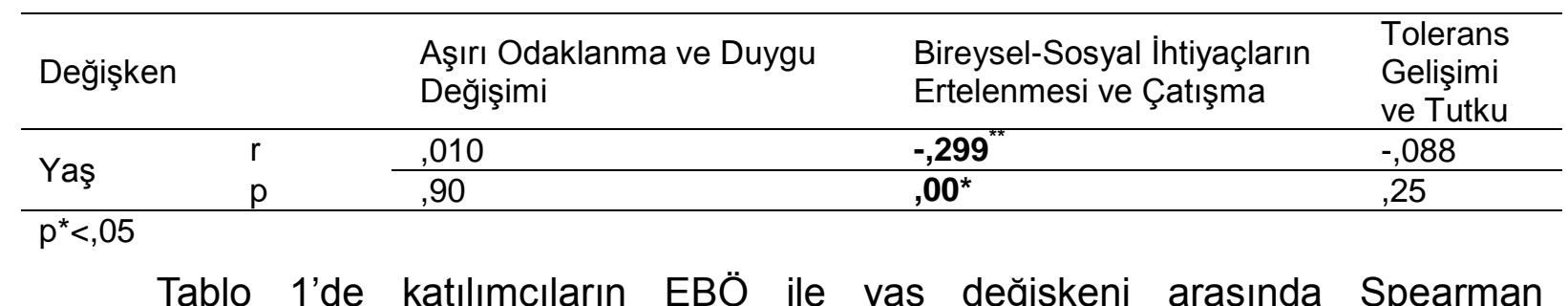

Korelasyon Testine ait bulgular yer almaktadır. Bu analiz sonucunda, yaş değişkeni ile bireysel-sosyal intiyaçların ertelenmesi ve çatışma alt boyutu arasında negatif yönde orta düzeyde anlamlı farklılık tespit edilmiştir $(r=-, 299 ; p<, 05)$.

Tablo 2. Cinsiyete Göre Yapılan Mann-Whitney U Testi Sonuçları

\begin{tabular}{|c|c|c|c|c|c|c|c|c|}
\hline EBÖ alt boyutları & $\begin{array}{l}\text { Medeni } \\
\text { durum }\end{array}$ & $N$ & $\overline{\mathrm{x}}$ & $\begin{array}{c}\text { Sıra } \\
\text { ortalaması }\end{array}$ & $\begin{array}{c}\text { Sıra } \\
\text { toplamı }\end{array}$ & $\begin{array}{c}\text { Mann } \\
\text { Whitney U }\end{array}$ & Z & $\mathrm{p}$ \\
\hline \multirow{2}{*}{$\begin{array}{l}\text { Aşırı Odaklanma } \\
\text { ve Duygu } \\
\text { Değişimi }\end{array}$} & Kadın & 82 & 28,14 & 64,01 & 5248,50 & \multirow[b]{2}{*}{1845,500} & \multirow[b]{2}{*}{$-1,809$} & \multirow[b]{2}{*}{,07 } \\
\hline & Erkek & 55 & 28,96 & 76,45 & 4204,50 & & & \\
\hline \multirow{2}{*}{$\begin{array}{l}\text { Bireysel-Sosyal } \\
\text { İhtiyaçların } \\
\text { Ertelenmesi ve } \\
\text { Çatışma }\end{array}$} & Kadın & 82 & 16,80 & 64,58 & 5295,50 & \multirow[b]{2}{*}{1892,500} & \multirow[b]{2}{*}{$-1,599$} & \multirow[b]{2}{*}{,11 } \\
\hline & Erkek & 55 & 17,85 & 75,59 & 4157,50 & & & \\
\hline Tolerans & Kadın & 82 & 13,21 & 65,04 & 5333,50 & \multirow[b]{2}{*}{2985,500} & \multirow[b]{2}{*}{$-1,413$} & \multirow[b]{2}{*}{,15 } \\
\hline $\begin{array}{l}\text { Gelişimi ve } \\
\text { Tutku }\end{array}$ & Erkek & 55 & 13,81 & 74,90 & 4119,50 & & & \\
\hline
\end{tabular}

Tablo 2'de katıımcıların cinsiyetleri ile EBÖ arasındaki anlamlı farklıı̆ğı tespit etmek amacıyla yapılan Mann Whitney $U$ testine ait bulgular görülmektedir. Yapılan analiz sonucunda katıımcıların cinsiyetleri ile egzersiz bağımlıı̆ı puanları arasında anlamlı farklılık saptanmamıştır ( $p>, 05)$. 
Batu, B. ve Aydın, A.D. (2020). Elit Yüzme Sporcularının Egzersiz Bağımlılığı Düzeylerinin İncelenmesi. Gaziantep Üniversitesi Spor Bilimleri Dergisi, 5(4), 399-412.

Tablo 3. Spor yaşına Göre Yapılan Spearman Korelasyon Analizi Sonuçları

\begin{tabular}{lcccc}
\hline Değişken & & $\begin{array}{l}\text { Aşırı Odaklanma ve } \\
\text { Duygu Değişimi }\end{array}$ & $\begin{array}{l}\text { Bireysel-Sosyal İhtiyaçların } \\
\text { Ertelenmesi ve Çatışma }\end{array}$ & $\begin{array}{l}\text { Tolerans Gelişimi } \\
\text { ve Tutku }\end{array}$ \\
\hline Yaş & $\mathrm{r}$ &, 063 &, 048 &, 008 \\
\hline $\mathrm{p}^{*}<, 05$ & $\mathrm{p}$ &, 41 &, 53 &, 92 \\
\cline { 3 - 6 }
\end{tabular}

Tablo 3'te katılımcıların spor yaşı ile arasında yapılan Spearman Korelasyon Testine ait bulgular yer almaktadır. Yapılan analiz sonucunda, spor yaşı ile EBÖ alt boyutları arasında anlamlı farklılık tespit edilmemiştir $(p>, 05)$.

Tablo 4. Yüzme stiline Göre Kruskal-Wallis Testi Sonuçları

\begin{tabular}{|c|c|c|c|c|c|c|}
\hline EBÖ alt boyutları & Yüzme stili & $\mathrm{N}$ & Sıra Ortalaması & $x^{2}$ & $p$ & Fark \\
\hline \multirow{4}{*}{$\begin{array}{l}\text { Aşııı Odaklanma ve Duygu } \\
\text { Değişimi }\end{array}$} & Serbest & 63 & 72,33 & \multirow{4}{*}{4,972} & \multirow{4}{*}{$\begin{array}{l}1 \\
7\end{array}$} & \multirow{4}{*}{ - } \\
\hline & Sırt Üstü & 23 & 71,30 & & & \\
\hline & Kurbağalama & 24 & 52,77 & & & \\
\hline & Kelebek & 27 & 73,69 & & & \\
\hline \multirow{4}{*}{$\begin{array}{l}\text { Bireysel-Sosyal İhtiyaçların } \\
\text { Ertelenmesi ve Çatışma }\end{array}$} & Serbest & 63 & 64,99 & \multirow{4}{*}{1,298} & \multirow{4}{*}{$\begin{array}{l}, 7 \\
3\end{array}$} & \\
\hline & Sırt Üstü & 23 & 73,24 & & & \\
\hline & Kurbağalama & 24 & 70,33 & & & \\
\hline & Kelebek & 27 & 73,56 & & & \\
\hline \multirow{4}{*}{ Tolerans Gelişimi ve Tutku } & Serbest & 63 & 69,60 & \multirow{4}{*}{$\begin{array}{r}10,62 \\
7\end{array}$} & \multirow{4}{*}{$\begin{array}{l}, 0 \\
1^{*}\end{array}$} & \multirow{4}{*}{$1-3$} \\
\hline & Sırt Üstü & 23 & 83,26 & & & \\
\hline & Kurbağalama & 24 & 47,56 & & & \\
\hline & Kelebek & 27 & 74,52 & & & \\
\hline
\end{tabular}

$\mathrm{p}^{*<, 05}$ Tablo 4'te katılımcıların yüzme stili ile egzersiz bağımlılığı düzeyi Kuruskal Wallis Testi ile incelenmiştir. Buna göre katılımcıları yüzme tekniği ile Tolerans Gelişimi ve Tutku arasında anlamlı farkııık tespit edilmiştir $(p<0,05)$. Lehine anlamlı farklılık gösteren gruplar * ile gösterilmiştir. Buna göre, sırt üstü stilinde yüzen sporcuların tolerans gelişimi ve tutku puanlarının $(\mathrm{SO}=83,26)$, serbest stil $(\mathrm{SO}=69,60)$ ve kurbağalama $(S O=47,56)$ stil yüzenlerin puan ortalamasından anlamlı düzeyde yüksek olduğu tespit edilmiştir (Ki-Kare=10,627; p<,05)

Tablo 5. Haftada Antrenman Yapma Sıklığına Göre Kruskal-Wallis Testi Sonuçları

\begin{tabular}{|c|c|c|c|c|c|}
\hline EBÖ alt boyutları & Antrenman sıklığı & $\mathrm{N}$ & Sıra Ortalaması & $x^{2}$ & $\mathrm{p}$ \\
\hline \multirow{3}{*}{$\begin{array}{l}\text { Aşırı Odaklanma ve Duygu } \\
\text { Değişimi }\end{array}$} & $1-2$ & 46 & 62,78 & \multirow{3}{*}{3,003} & \multirow{3}{*}{ 22 } \\
\hline & $3-4$ & 59 & 68,69 & & \\
\hline & 5 ve üstü & 32 & 78,50 & & \\
\hline \multirow{3}{*}{$\begin{array}{c}\text { Bireysel-Sosyal İhtiyaçların } \\
\text { Ertelenmesi ve Çatışma }\end{array}$} & $1-2$ & 46 & 69,00 & \multirow{3}{*}{2,777} & \multirow{3}{*}{ 24 } \\
\hline & $3-4$ & 59 & 63,92 & & \\
\hline & 5 ve üstü & 32 & 78,38 & & \\
\hline \multirow{3}{*}{ Tolerans Gelişimi ve Tutku } & $1-2$ & 46 & 64,53 & \multirow{3}{*}{1,342} & \multirow{3}{*}{,51 } \\
\hline & $3-4$ & 59 & 69,20 & & \\
\hline & 5 ve üstü & 32 & 75,05 & & \\
\hline
\end{tabular}


Batu, B. ve Aydın, A.D. (2020). Elit Yüzme Sporcularının Egzersiz Bağımlılı̆̆ı Düzeylerinin İncelenmesi. Gaziantep Üniversitesi Spor Bilimleri Dergisi, 5(4), 399-412.

Tablo 5'te katıımcıların EBÖ ile haftada antrenman yapma sıklığı arasında Kruskal-Wallis Testine ait bulgular yer almaktadır. Yapılan analiz sonucunda, haftada antrenman yapma sıklığı ile EBÖ arasında anlamlı farklılık tespit edilmemiştir $(p>, 05)$.

\section{Tartışma ve Sonuç}

Bu araştırmada elit yüzme sporcularının yaş, cinsiyet, spor yaşı, yüzme stili ve egzersiz yapma sıklı̆̆ değişkenlerine göre egzersiz bağımlılı̆ı düzeylerinin incelenmesi amaçlanmıştır.

Araşıımanın birinci bulgusunda katılımcıların EBÖ ile yaş değişkeni arasındaki ilişki incelenmiştir. Buna göre, sporcuların yaşı ile bireysel-sosyal intiyaçların ertelenmesi ve çatışma alt boyutu arasında negatif yönde orta düzeyde anlamlı farklılık saptanmışı̧ı. Araştırmaya katılan yüzme sporcularının yaşları artııça bireysel-sosyal intiyaçların ertelenmesi ve çatışma düzeylerinin arttığı söylenebilir. Bu bağlamda sporcuların yaşı arttıkça egzersize olan düşkünlüğünün artıı̆ı, egzersiz yapmak için iş veya randevusunu aksattığı, egzersiz yapmaktan sosyal faaliyetlere (kültürel, sanatsal, vb..) zamanının kalmadığı söylenebilir. Araştırma bulgularına paralel olarak başka bir araştırmada elit sporcuların yaşları arttıkça egzersiz bağımlılığı düzeylerinin de arttığı belirtilmiştir (Cicioğlu ve ark., 2019). Literatürde egzersiz bağımlıı̆ı ile yaş arasında anlamlı farklılık tespit elde etmeyen araştırmalar yer almaktadır. Yapılan incelemede spor bilimleri fakültesi öğrencilerinin egzersiz bağımlıı̆ı düzeyleri ile yaş değişkeni arasında anlamlı bir farklıık tespit edilememiştir (Demir ve Türkeli, 2019). Başka bir çalışmada Orhan ve arkadaşları (2019) spor merkezlerinde egzersiz bağımlılığının incelenmesi çalışmasında yaş değişkeninin egzersiz bağımlıı̆ğına etkisi olmadığını tespit etmiştir. Bootan(2018) ve Sadıq(2018), farkı branş sporcuları üzerinde yaptıkları çalışmada egzersiz bağımlıı̆ı̆ düzeyleri ile sporcu yaşı arasında anlamlı farklılık olmadığını rapor etmişlerdir. Bu çalışmalara benzer çalışmalarda yaş ile egzersiz bağımlıı̆ı düzeyi arasında araştırma bulgularının zıttı sonuçlar rapor edilmiştir (Hamer, Karageorghis, 2007). Yetişkinler üzerinde yapılan çalışmada da bulgularımızın tersi yönünde sonuçlar rapor edilmiştir (Uçar, 2019).

Araştırmanın ikinci bulgusunda katıımcıların cinsiyeti ile EBÖ arasındaki ilişki incelenmiştir. Yapılan araştırma sonucunda sporcuların cinsiyeti ile egzersiz bağımlılığı alt boyutları arasında anlamlı bir farklılık görülmemiştir. Buna göre 
Batu, B. ve Aydın, A.D. (2020). Elit Yüzme Sporcularının Egzersiz Bağımlılığı Düzeylerinin İncelenmesi. Gaziantep Üniversitesi Spor Bilimleri Dergisi, 5(4), 399-412.

sporcuların egzersize karşı duydukları heyecanın cinsiyet ile bağlantılı olmadığı söylenebilir. Aynı zamanda egzersize verilen değere ve harcanan zamana da cinsiyetin bir etkisi olmadığı ifade edilebilir. Araştırma bulgularına benzer olarak Çetin ve arkadaşlarının (2020) elit atletlerin performansları ile egzersiz bağımlılı̆ı ilişkisini incelendiği araştırmada, kadın ve erkek atletlerin egzersiz bağımlılığı düzeylerinin yüksek olduğu ve farklılık göstermediği saptanmıştır. Uz (2015) tarafından yapılan araştırmada, düzenli olarak spor salonlarına giden bireylerin cinsiyet değişkeniyle egzersiz bağımlıı̆̆ toplam puanları arasında istatistiksel anlamda bir farklılık olmadığı rapor edilmiştir. Bu çalışmalara paralel olarak literatürde birçok araştırma bulunmaktadır (Bootan, 2018; Cicioğlu vd., 2019; Sadıq, 2018; Vardar, 2012; Yeltepe, 2005; Yıldırım vd., 2017). Araştırma bulgularından farklı olarak bazı araştırmacılar egzersiz bağımlılığı riski taşıma açısından kadınları işaret ederken (Davis, 1990), Demir ve Türkeli (2019) tarafından yapılan araştırmada bireysel-sosyal intiyaçların ertelenmesi ve çatışma alt boyutunda, erkeklerin ortalamasının kadınlardan daha yüksek olduğu tespit edilmiştir.

Araştırmada, katıımcıların spor yaşı ile EBÖ arasındaki ilişki incelenmiştir. Inceleme sonucunda spor yaşı ile egzersiz bağımlıı̆̆ı alt boyutları arasında anlamlı bir farklılık tespit edilmemiştir. Buna göre spor yaşının, sosyal faaliyetlere ayrılan zamana ve egzersiz sürelerine de herhangi bir etkisi olmadığı söylenebilir. Cicioğlu vd. (2019), elit sporcular ve spor bilimleri fakültesi öğrencileri üzerindeki çalışmasında spor yaşının arttıkça egzersiz bağımlıı̆ı düzeyinin artıı̆ı rapor etmiş olsalar da araştırmada elit yüzme sporcularının spor yaşındaki artışın egzersiz bağımlıı̆ı̆ düzeyi üzerinde bir değişikliğe sebep olmadığı, egzersiz yapmaktan duyulan mutlulukla ilişkisi olmadığı gözlemlenmiştir. Uzun (2019) tarafından spor bilimleri eğitimi alan yüksek öğretim öğrencilerinin üzerinde yapılan çalışmada, egzersiz alt boyutları ile spor yaşı arasında anlamlı bir farklııı tespit edilememiştir. Polat ve Şimşek (2015), egzersiz yaşına göre geri çekilme, devamlılık, tolerans, kontrol kaybı ve zaman boyutlarında farklılaşma tespit etmiş ve spor yaşının 7 yıl ve üzeri olmasının bu farklılaşmada etkili olduğunu savunmuştur. Birgönül (2019) ise tenis sporuna yönelik yaptığı çalışmada spor yaşı 1-4 yıl olan sporcular ile 15-19 yıl olan sporcular arasında yapılan testte egzersiz bağımlıı̆ı açısından anlamlı farklılık olduğunu belirtmiştir.

Araştırmada katılımcıların yüzme stili ile EBÖ arasındaki ilişki incelenmiştir. Buna göre katıımcıların yüzme stilleri ile tolerans gelişimi ve tutku alt boyutu 
Batu, B. ve Aydın, A.D. (2020). Elit Yüzme Sporcularının Egzersiz Bağımlılığı Düzeylerinin İncelenmesi. Gaziantep Üniversitesi Spor Bilimleri Dergisi, 5(4), 399-412.

arasında anlamlı bir farklılık vardır. Bu bağlamda sırt üstü yüzen katıımcıların serbest ve kurbağalama yüzenlere oranla puanlarının anlamlı bir düzeyde yüksek olduğu tespit edilmiştir. Bu sonuca göre sırt üstü yüzen katıımcıların egzersiz yapmayı sabırsızlıkla bekledikleri ve egzersiz sürelerini uzattıkları düşünülebilir. Elde edilen bu sonuca göre serbest ve kurbağalama yüzen sporcuların egzersize ayırdıkları sürenin, sırt üstü yüzen sporcuları tatmin etmediği ve sırt üstü yüzen sporcuların daha fazla egzersiz yapmaya zaman ayırdıkları söylenebilir. Literatürde yüzme sporcuları ile ilgili bu doğrultuda bir çalışmaya rastlanmamıştır fakat Çetin ve arkadaşlarına (2020) göre, egzersiz bağımlıı̆ı ile egzersize fazla maruz kalma arasında güçlü bir ilişki vardır. Sporcuların en üst düzeydeki başarıya odaklanması, yaşamlarının merkezine egzersizi koyması ve vazgeçilmez bir yol olarak görmesinden dolayı egzersiz bağımlılığı ile yüz yüze kalması kaçınılmazdır.

Araştırmanın son bulgusunda katıımcıların haftalık antrenman yapma sıklığı ile EBÖ arasındaki ilişki incelendiğinde, sporcuların haftalık antrenman yapma sıkıkları ile egzersiz bağımlıı̆ı alt boyutları arasında anlamlı bir farklılık saptanmamışır. Spor yapmayı düzenli hale getirmekle egzersiz bağımlılığı, özellikleri açısından farklıık göstermektedir. Spor yapayı rutin hale getirenlerin sosyal aktivitelere katıımı, aile bireyleri ve çevreleri ile etkileşim içinde olmaları beklenirken, egzersiz bağımlılığında sosyalleşmek yerine egzersiz sıklığının artması beklenir. Ayrıca düzenli şekilde yapılan spor zamanında ve süresinde sınırlılıklar varken egzersiz bağımlıı̆̆ı olanlarda egzersiz yapma süresinin sürekli olarak artış gösterdiği bilinmektedir. Çünkü egzersiz bağımlılarının egzersizden kendini alamama, egzersiz yapmadıklarında bile egzersiz yapma hayali kurması beklenir (Adams vd., 2003; Adams, 2009; Hausenblas ve Downs, 2002). Yıldızçiçek (2019) araştırmasında, fitness salonunda 30 yaş üstünde kişilerin yaptığı düzenli egzersizin, egzersiz bağımlılığı üzerinde bir etkiye sahip olduğu sonucuna ulaşılmıştır. Farklı bir araştırmada da egzersiz sıklığının, egzersiz bağımlıığının bir sebebi olabileceği sonucuna ulaşıımıştır (Costa, 2012). Spor bilimleri fakültesi öğrencileri üzerinde yapılan çalışmada da Demir ve Türkeli (2018), spor yapma sıklığına göre egzersiz bağımlıığı düzeyinde farklılık oluştuğunu rapor etmiştir. Büyüköztürk ve ark. (2017) elit sporcuların düzenli olarak egzersiz yapmaları ve zamanla bu egzersizlerin bağımlılığa dönüştüğünü belirtmiştir fakat elit yüzme sporcuları üzerinde yapılan çalışmada düzenli antrenman yapan sporcuların, antrenman sıklığı ile egzersiz bağımlılığı arasında herhangi bir ilişki gözlenmemiştir. 
Batu, B. ve Aydın, A.D. (2020). Elit Yüzme Sporcularının Egzersiz Bağımlılığı Düzeylerinin İncelenmesi. Gaziantep Üniversitesi Spor Bilimleri Dergisi, 5(4), 399-412.

Özetle, araştırmada elit yüzme sporcularının egzersiz bağımlıı̆ı düzeylerinin stillerine ve yaşlarına göre bağımlı grupta yer aldığı sonucuna varıımıştır. Sporcuların performanslarını artırmak için egzersize yönelimi de artırmaları beklenebilir. Fakat bunun planlı, programlı yapılması ve performans odaklı eğitime katılmaları gerekmektedir. Böylece sporcuların egzersiz bağımlılığından korunmaları ve sporcularda bağımlılık belirtilerinin belirlendiği noktadan itibaren tedavi edilmesi söz konusu olabilir. Nitekim sporcular performans odaklı eğitime katıldıkça, giderek daha zorlayıcı egzersiz programlarını çok dikkatli bir şekilde planlayabilirler ve büyük bir koç, doktor, fizyoterapist, diyetisyen ve masör vb. ile birlikte çalışabilirler (Szabo, 2018).

\section{Kaynaklar}

Adams, J. (2009). Understanding exercise dependence. Journal of Contemporary Psychotherapy, 39(4), 231-240

Adams, J.M., Miller, T.W., ve Kraus, R.F. (2003). Exercise dependence: diagnostic and therapeutic issues for patients in psychotherapy. Journal of Contemporary Psychotherapy, 33(2), 93-107.

Amerikan Psikiyatri Birliği (2001). Psikiyatride Hastalıkların Tanımlanması ve Sınıflandırılması Elkitabı, Yeniden Gözden Geçirilmiş 4. Baskı (DSM-IV-TR) (E Köroğlu, Çev.). Ankara, Hekimler Yayın Birliği

Berczik, K., ve ark. (2012). Exercise Addiction: Symptoms, Diagnosis, Epidemiology, and Etiology. Substance Use ve Misuse, 403-417.

Birgönül, Y., (2019). Tenis Sporuna Yönelik Egzersiz Bağımlıı̆ı Ve Huzur İlişkisi, Balıkesir Üniversitesi Sağlık Bilimleri Enstitüsü, Yüksek Lisans Tezi, Balıkesir

Bootan, J. S. (2018). Kickboks, Taekwondo ve Muay Thai Sporcularının Egzersiz Bağımlıı̆ının Araştırılması,Yüksek Lisans Tezi, Fırat Üniversitesi, Sağlık Bilimleri Enstitüsü, Beden Eğitimi ve Spor Anabilim Dalı, Elazığ.

Bozdoğan, A. (2006). Yüzme. İstanbul: Morpa Kültür Yayınları.

Büyüköztürk Ş, Çakmak EK, Akgün ÖE, Karadeniz Ş, Demirel F. (2017). Bilimsel Araştırma Yöntemleri, Ankara, Pegem Atıf İndeksi, 301

Cicioğlu, H. İ., Tekkurşun Demir, G., Bulğay, C. ve Çetin, E. (2019). Elit Düzeyde Sporcular ile Spor Bilimleri Fakültesi Öğrencilerinin Egzersiz Bağımlıı̆ı Düzeyleri, Bağımlılık Dergisi, 20(1), 1-5. 
Batu, B. ve Aydın, A.D. (2020). Elit Yüzme Sporcularının Egzersiz Bağımlılığı Düzeylerinin İncelenmesi. Gaziantep Üniversitesi Spor Bilimleri Dergisi, 5(4), 399-412.

Costa S, Cuzzocrea F, Hausenblas HA, Larcan R, Oliva P. (2012). Psychometric examination and factorial validity of the Exercise Dependence Scale-Revised in Italian exercisers. J Behav Addict, 1(4), 186-190.

Çetin, E., Bulğay, C., Demir, G. T., Cicioğlu, H. İ., Bayraktar, I., ve Orhan, Ö. (2020). The Examination of the Relationship Between Exercise Addiction and Performance Enhancement in Elite Athletes. International Journal of Mental Health and Addiction, 1-12.

Davis, C. (1990). Weight and Diet Preocupation and Addictiveness: The Role of Exercise, Personality and Individual Differences, 11, 823-827.

Demir, G. T., Hazar, Z. ve Cicioğlu, H. İ. (2018). Exercise Addiction Scale (EAS): A Study of Validity and Reliability. Kastamonu Education Journal, 26(3), 865874.

Demir, G. ve Türkeli, A. (2019). Spor Bilimleri Fakültesi Öğrencilerinin Egzersiz Bağımlılığı ve Zihinsel Dayanıklılık. Spor Bilimleri Araştırma Dergisi 4(1), 1025.

FZmijewsk, C. ve Howard, M. (2000). Exercise dependence and attitudes toward eating among young adults. Eating Behaviors, 181.

Gonul, T. D., Aynur, Y., Oguz, K. E. ve Ekrem, L. I. (2016). Why does my child swim? Mechanism of parent guidance. Ovidius University Annals, Series Physical Education and Sport/Science, Movement and Health, 16(2 SI), 442-449.

Hamer M, Karageorghis, Cl. (2007). Psychobiological mechanisms of exercise dependence. Sports Med, 37(6), 477-484.

Hannula, D. (2001). The Swim Coaching Bible. Human Kinetics. 21-133

Hausenblas, H.A., ve Downs, D.S. (2002). Exercise dependence: a systematic review. Psychology of Sport and Exercise, 3(2), 89- 123.

Koruç, Z., ve Arsan, N. (2009). Egzersiz Davranışını İzleyen Etmenler: Egzersiz Bağlılı̆ı Ve Egzersiz Bağımlıığı. Spor Hekimliği Dergisi, 105-113.

Menteş, E., Menteş, B., ve Karacabey, K. (2011). Adölesan Döneminde Obezite ve Egzersiz. Uluslar Arası İnsan Bilimleri Dergisi, cilt:8 sayı:2.

Odabaş B., (2003). 12 Haftalık Yüzme Temel Eğitim Çalışmalarının 7-12 Yaş Gurubu Kız ve Erkek Yüzücülerin Fiziksel ve Motorsal Özellikleri Üzerine Etkisi, Kocaeli Üniversitesi Sağlık Bilimleri Enstitüsü, Yüksek Lisans Tezi, Kocaeli.

Orhan S, Yücel AS, Gür E, Karadağ M. Spor merkezlerinde egzersiz bağımlılığının incelenmesi. Turkish Studies, 2019, 14(2): 669-678. 
Batu, B. ve Aydın, A.D. (2020). Elit Yüzme Sporcularının Egzersiz Bağımlılığı Düzeylerinin İncelenmesi. Gaziantep Üniversitesi Spor Bilimleri Dergisi, 5(4), 399-412.

Ögel, K., ve Akt: Cicioğlu ve ark. (2019). Elit Düzeyde Sporcular ile Spor Bilimleri Fakültesi Öğrencilerinin Egzersiz Bağımlılığı Düzeyleri. Bağımlılık Dergisi Journal of Dependence.

Özer , K. (2013). Fiziksel Uygunluk. İstanbul: Nobel Yayınevi.

Patton, M. Q. (2014). Qualitative research ve evaluation methods: Integrating theory and practice. Sage publications.

Polat, C., ve Şimşek, K. (2015). Spor merkezlerindeki bireylerin egzersiz bağımlılı̆ı düzeylerinin incelenmesi: Eskişehir İli Örneği. Akademik Sosyal Araştırmalar Dergisi, 354-369.

Sadıq, B. J. (2018). Investigation of the exercise dependence of Athlets' Kick Boxing, Taekwondo and Muay Thai. Fırat University, Institute of Health Sciences Department of Physıcal Education and Sports Master Thesis.

Szabo, A. (2018). Addiction, passion, or confusion? New theoretical insights on exercise addiction research from the case study of a female body builder. Europe's Journal of Psychology, 14(2), 296-316.

Tanrıverdi, H. (2012). Spor Ahlakı ve Şiddet. Publication of Association Esprit, Societe et Rencontre, 1071-1093.

Turkay, H., Mumcu, H.E., Çeviker, A., Güngöz, E., ve Özlü, K. (2019). Beden eğitiminde temel psikolojik intiyaçlar ölçeğinin Türkçe'ye uyarlanması. Gazi Üniversitesi Eğitim Fakültesi Dergisi, 39(2), 1135-1155.

Uçar, SA. (2019). Yetişkinlerde Egzersiz Bağımlıı̆ı İle Narsisizm Arasındaki Illişkinin Incelenmesi. Yüksek Lisans Tezi. Bursa Uludağ Üniversitesi Eğitim Bilimleri Enstitüsü.

Uzun, U. (2019). Spor bilimleri eğitimi alan yüksek öğretim öğrencilerinin egzersiz bağımlılığının incelenmesi. Yüksek Lisans Tezi. Trakya Üniversitesi, Sosyal Bilimler Enstitüsü.

Uz, İ. (2015). Fitness merkezlerine düzenli katılan bireylerde egzersiz bağımlılığın incelenmesi. Yayımlanmamış Yüksek Lisans Tezi. Çanakkale Onsekiz Mart Üniversitesi, Sağlık Bilimleri Enstitüsü. Çanakkale.

Vardar, E. (2012). Egzersiz Bağımlıı̆̆ı. Arşiv Kaynak Tarama Dergisi, 163-173.

Yeltepe, H. (2005). Egzersiz Bağımlıı̆ıının Tanımlanması ve "Egzersiz Bağımlıı̆ı Ölçeği-21" in Geçerlilik ve Güvenilirlik Çalışmasının Yapılması, Yayımlanmış Yüksek Lisans Tezi, Marmara Üniversitesi Sağlık Bilimleri Enstitüsü. 
Batu, B. ve Aydın, A.D. (2020). Elit Yüzme Sporcularının Egzersiz Bağımlılığı Düzeylerinin İncelenmesi. Gaziantep Üniversitesi Spor Bilimleri Dergisi, 5(4), 399-412.

Yıldırım, İ., Yıldırım, Y., Ersöz, Y., Işık, Ö., Saraçlı, S., Karagöz, Ş., ve Yağmur, R. (2017). Egzersiz bağımlılığı, yeme tutum ve davranışları ilişkisi. CBÜ Beden Eğitimi ve Spor Bilimleri Dergisi, 12(1), 43-54.

Yıldırım, N., ve Akın, U. (2017). Öğretmenlerin Eğitime İnanma Düzeylerinin Çeşitli eğişkinler Açısından İncelenmesi. Mersin Üniversitesi Eğitim Fakültesi Dergisi, 213-227.

Yıldızçiçek, C. (2019). Psikolojik Bir Rahatsızlık Olan Egzersiz Bağımlılığının Öz Yeterlilik İle İlişkisinin İncelenmesi, Yayımlanmış Yüksek Lisans Tezi, Kütahya Dumlupınar Üniversitesi Sosyal Bilimler Enstitüsü.

Yılmaz, A., Şentürk, U., ve Ramazanoğlu, F. (2014). Bedensel Engellilerde Spor Konulu Araştırmaların İçerik Analizi. Spor Yönetimi ve Bilgi Teknolojileri Dergisi, Cilt:9 sayı:1-2. 